\title{
IAMJ
}

INTERNATIONAL

AYURVEDIC

MEDICAL JOURNAL

(6) 2 (1)

Review Article

ISSN: $2320-5091$

Impact Factor: 6.719

\section{AYURVEDIC CONCEPT OF LEUCORRHOEA: SWETA PRADARA}

\section{$\underline{\text { Krishnapriva }}^{1}, \underline{\text { Kavitha B K }}^{2}$}

${ }^{1}$ PG Scholar, Department of Prasuti Tantra, Alva's Ayurveda College, Moodbidri, India

${ }^{2}$ Associate Professor, Department of Prasuti Tantra, Alva's Ayurveda college, Moodbidri, India

Corresponding Author: aonandakumar@gmail.com

\section{https://doi.org/10.46607/iamj4209092021}

(Published Online: September 2021)

Open Access

(C) International Ayurvedic Medical Journal, India 2021

Article Received: 26/08//2021 - Peer Reviewed: 04/09/2021 - Accepted for Publication: 05/09/2021

\section{Check for updates}

\begin{abstract}
Leucorrhoea is one of the most common and burning problems faced by women all around the globe. It may be physiological but when turning into a pathological condition, produce associated symptoms like itching vulva, backache, and anxiety to female suffering from the entity. Various factors like fungal, parasite, bacterial, and sexually transmitted diseases are responsible for the causation of this disease. In Ayurveda, it is termed as Sweta pradara. It can be a symptom of many diseases as well as an independent entity. No description of Sweta Pradara has been described by scholars of Brihatrayee. For abnormal white vaginal discharges, the word Sweta Pradara has been described in texts during and after the medieval period. The present study has been designed to substantiate the aetiology, pathogenesis, clinical features and treatment of sweta pradara so that alternative better forms of therapy can be made available in those suffering from Sweta pradara.
\end{abstract}

Keywords: Sweta Pradara, Leucorrhoea, Yonivyapad.

\section{INTRODUCTION}

Leucorrhoea is one of the most common gynaecological disorders characterized by the whitish discharge from the genitals. Normally vaginal discharge happens in regular variations of amount and consistency during the menstrual cycle. A greater than usual amount is normal in pregnancy, and a decrease to be expected after delivery, during lactation and after menopause. 
Physiological vaginal discharge may not require specific treatment. However pathological conditions involving infections like Vaginal candidiasis, Trichomonas, Gram-negative and positive organisms may necessitate its management.

In Ayurveda classics, it is known as Sweta pradara. Due to improper diet and regimens, kapha gets aggravated and reaches the genital tract and vitiates rasa dhatu of the reproductive system causing discharge of the white coloured foul-smelling fluid. It has been estimated that nearly $60-80 \%$ of women suffer from this at some time or other. Normal vaginal discharge may appear clear, cloudy white and without any type of smell. Changes in normal discharge can be caused by many reasons such as menstrual cycle, emotional stress, nutritional status, pregnancy, usage of medications - including birth control pills and sexual arousal. The menstrual cycle affects the vaginal environment i.e., $\mathrm{pH}$ of the vagina. Any changes in colour, consistency, amount, the smell of discharge may be a sign of abnormal vaginal infection. It may be due to the attack of yeast, bacteria, hormonal imbalance, constipation, improper hygiene habits, anemia, diabetes and indigestion also.

Ayurveda, an ancient science of life is enriched with the knowledge of gynaecological disorders related to vaginal discharges which may be blood-stained or pinkish, mucoid, purulent, white-thin, thick, curdy or watery. White vaginal discharge is known as Sweta pradara in Ayurvedic classics. Sweta Pradara (Leucorrhoea) is not a disease, but a symptom of so many diseases

\section{ETIOPATHOGENESIS}

Leucorrhoea is a symptom, not a disease, thus etiopathogenesis of principal disease would be etiopathogenesis of this condition also. However, based on clinical features, it appears to be a disease of vitiation of kapha, thus etiopathogenesis may be considered in the following way. So, it may be said that Kapha aggravated due to its vitiating factors, influences, or vitiates the rasadhatu of the reproductive system, already influenced by excessive coitus, abortion, improper mode of life and dietetics during menstruation and Ritukala along with non-cleanliness and then produces white and painless vaginal discharges due to dominance of its liquid property.

\section{TYPES OF LEUCORRHOEA}

1) Physiological

2) Pathological

\section{Physiological Leucorrhoea}

Normal vaginal discharge consists of secretions from glands of the cervix, vagina and endocervical mucus. The discharge is usually transparent to white coloured and odourless. Changes in estrogen level can affect vaginal discharge, when levels are high estrogen stimulates the cervix to produce secretions and a small amount of mucus may be discharged from the vagina. Leucorrhoea has the following functions

1) Defence mechanism

2) To maintain the flexibility of the vagina

\section{Pathological Leucorrhoea}

The discharge will be yellow, green, white, has an offensive odour and be accompanied by irritation, itching, pain or tissue inflammation. This may be caused by infections with bacteria, yeast, or other organisms. Psychological factors are most common in this. The discharge also happens due to the defective vaginal defence mechanism.

\section{CLINICAL FEATURES}

There is no direct mention of the rupa of Sweta pradara in classical texts of Ayurveda, one can get indirect references to Sweta srava at several places while dealing with yonivyapad. In Kaphaja Yonivyapad Charaka states that Pichila, Sheeta, Panduvarna, Kanduyuktha and Alpavedana yukta yonisrava is seen. Similarly, in Upapluta yonivyapad, Charaka mentioned that there is Sweta yonisrava which is pandu varna and along with toda. He says that this srava is due to vata and kapha. However, this sweta srava is specific to Garbhini stree.

Chakrapani has explained pandura asrugdara as sweta pradara and Indu as sukla asrugdara. Swetapradara is a condition characterized by white vaginal discharges not associated with pain, burning sensation and mixed with other colours, thus it seems to be the description of leucorrhoea. 
The patient feels foul-smelling vaginal discharge, itching sensation in the vagina, pain in the stomach, lumbar region and calves, constipation, and headache. In young females, threadworms may cause the onset of this disorder. In mature ladies, inflammation of the uterus (following childbirth) may also trigger and hasten leucorrhoea flow.

\section{INVESTIGATIONS}

The following investigations should be done to confirm the diagnosis and for proper treatment to cure the disease.

1) Examination of blood $=\mathrm{Hb} \%$ total count, differential count.

2) Blood sugar.

3) Urine examination: Routine \& microscopic.

4) USG (Abdomen\& Pelvis).

5) Pap Smear, VDRL (Venereal disease research laboratory test), HIV.

\section{TREATMENT}

The principle of Ayurvedic treatment of Sweta Pradara is mostly based on its etiopathogenesis. As Kapha is the main causative factor for vaginal discharge

\section{Treatment consists of two headings}

1). Samanya chikitsa (General line of treatment).

2). Vishesha chikitsa (Specific line of treatment).

\section{General treatment}

a. Nidana parivarjana - It is the basis of the management of all diseases. Nidana facilities treatment if the causes of the treatment of the diseases are traced out. Further in most cases when the cause of the disease is removed, the disease subsides naturally. In Sweta pradara the causative factors should be avoided to get permanent relief. For example- Mithya ahara and vihara.

b. Kaphasamana treatment- If discharge per vagina is especially white in colour, pichila srava, kandu yukta then it is due to disordered kapha, the main aim would naturally be to bring kapha to its normal state. For this various Kaphaghna drugs are advised. The main characteristics of these drugs are Ruksha and Usna. While administering various Kaphaghna drugs accompanying Dosha dushti and Dhatu- Veishamya must be considered.

c. Symptomatic treatment of Yonisrava and Yonipaichhilya.

d. Balya chikitsa - It plays an important role to prevent the incidence and treat the disease.

e. Usage of katu and kashaya rasa dravyas- These dravyas alleviates kapha.

\section{Specific treatment}

1) Oral medicines

a) Pestled root of Rohitaka should be taken with water.

b) Pestled fruit of amalaki mixed with madhu and sarkara should be taken after mixing with jala.

c) Paste of lodhra mixed with a decoction of stembark of nyagrodha should be taken.

d) The use of a decoction of drugs of Nyagrodha group is beneficial due to its astringent property.

e) Use of Nagakeshara (Mesua ferrea L.) with Takra (buttermilk) followed by a diet of only cooked rice and Takra can cure leucorrhoea only within three days.

f) Powder of root of Chakramarda (Cassia tora L.) should be taken with Tandulodaka (rice- water) in the morning hours.

g) Licking powdered padawasa (a variety of Setaria etallica) mixed with oil of Tila for seven consecutive days cures leucorrhoea.

h) Pushyanuga churna should be used with Tandulodaka mixed Madhu.

i) Pradarantaka lauha, Pradarantaka rasa, Pradarari rasa, Pradararipu rasa, Pradarari lauha, Shitakalyanaka ghrita etc. are Rasaushadhi, mentioned in Bhaishajya ratnavali to cure the Sweta pradara.

j) Ghrita-Taila: Ashoka ghrita, Nyagrodhadi ghrita, Vishwavallabha ghrita and Priyangwadi taila Asava-Arishta: Lakshmanarishta, Ashokarishta, Patrangasava and Lodhrasawa.

k) Kukkutandatwak bhasma 250mg with Madhu (honey) twice a day.

2) Drugs for external or local use:

A. Yoni Prakshalana 
a) Vaginal irrigation with a decoction of stembark of lodhra

b) Vaginal irrigation with a decoction of vata.

B. Yoni Purana

1) After oleating the vaginal canal, a bolus made with powdered bark of plaksa mixed with honey should be placed.

2) Fine powders of Khadira, Pathya, Jatiphala, Nimba, and Puga, triturated with soup of Mudga and used in vagina after drying the mixture

C. Yoni-Varti

1) Suppository made with powdered lodhra, priyangu, and madhuka mixed with Madhu or else with kasaya(astringent) drugs should be placed in oleated vaginal canal

D. Yoni-Dhupana

1) After oleating vaginal canal, fumigation with sarala, guggulu, and yava mixed with plenty of ghrta or else katu matsyaka along with oil should be done

Pathya: meat soup, rice water, all dairy products and garlic

Apathya: Sweet and sour fruits, nuts, and excess salt. Preventive Measures

- Avoid vulvo/vaginal irritants, including perfumed or deodorant soaps/body washes.

- Don't scratch infected or inflamed areas; it can cause further irritation

- Wash the genitals carefully during every bath and do not let moisture retain in the genital area after the bath.

- Avoid synthetic or nylon undergarments. Wear cotton undergarments

- Don't wash the undergarments with strong detergents.

- Use the medication as long as directed.

\section{DISCUSSION}

Leucorrhoea is the most common and certainly the most annoying problem confronting the gynaecologist in practice. The result of recent surveys in this regard shows a picture that an estimated $75 \%$ of women experience at least one episode of vaginal infections dur- ing their lifetimes. The most common causes of leucorrhoea in modern are cervicitis, vaginitis, cervical erosion, and bacterial vaginosis. If neglected it also points to serious underlying obstetrics and gynaecological complications.

Sweta pradara is predominantly a kapha vataja disorder. Kapha can be considered as the main causative factor by its vitiated snigdha does not occur without the involvement of vata dosha. Moreover, any type of yoniroga does not occur without the involvement of vata dosha, vitiation of vata occurs chiefly by its chala guna. Though kapha and vata seem to be leading doshas responsible for Swetapradara the role of pitta cannot be neglected here as any disease in Ayurveda involves all the three doshas through predominance varieties. Pitta is vitiated mainly by its visra, sara and drava guna. So Swetapradara can be considered as kapha vata pradhana tridoshaja vyadhi. Since ancient times various treatment modalities explained in different forms with the drugs available in nature. Ayurveda explains both oral and local procedures. Treatment of Swetapradara is mainly based on the use of drugs which are having a predominance of Kashaya rasa and Kapha-shamaka property. Therefore, the drugs of Kashaya rasa dominance are mainly used locally and internally.

For this treatment sthanika chikitsa plays an important role here. The vaginal wall is very well suited for the absorption of drugs since it contains a vast network of blood vessels. The drugs used for sthanika chikitsa acts by exerting their antiseptic, antimicrobial, antifungal, anti-inflammatory and analgesic actions. Here proper Sthanika chikitsa with proper internal medicines gives potentially good results in the treatment of sweta pradara

\section{CONCLUSION}

Leucorrhoea is the most common and certainly the most annoying problem confronting the gynaecologist in practice. Increased incidences and recurrence rates of Swetapradara directly implies the need for a treatment that not only cures it but prevent its recurrence. There are various oral and local treatments available 
for Swetapradara in our classics. Treatment of Swetapradara is mainly based on the use of drugs which are having a predominance of Kashaya rasa and Kapha-shamaka property.

\section{REFERENCES}

1. Achaya Charaka, Charaka Samhita (Uttarardha), Hindi Translation by Pandit Kashinath Nath Shastri and Dr Gorakh Nath Chaturvedi, Reprint, Varanasi, Chaukhambha Sanskrit Series, page no- 30/11.

2. Acharya Vagbhata, Astanga Sangraha, Sanskrit Commentary by Vaidya Anant Damodar Athawale, Pune, Shreemada Atreya Athawale, 1980

3. Yoga Ratnakara: Hindi Commentary by Achrya Laxmipati Shastri, Published by chaukhambha Sanskrita Series Office, Varanasi. 2nd Edition, 1973

4. Acharya Sharandhara, Sharandhara Samhita, Dipika Hindi Commentary by Brahmanand Tripathi, Reprint, Varanasi, Chaukhambha Shubharati Prakashana, 2001, p 149

5. Sri Govindacharya, Bhaisajya Ratnavali with Vidyotini Hindi commentary by Sri Kaviraja Ambikadatta Shastri edited by Acharya Rajeshwaradatta Shastri, 17th edition, Varanasi, Chaukhambha Publications, 2004 p. 853-854.

6. Acharya Bhava Mishra, Bhav Prakash Nighantu, Uttarkhanda, Hindi Commentary by Shree Brahma Shankar Mishra, 4th edition, Varanasi, Chaukhambha Vishwabharati, 1988. p. 764.

7. Tivari Premvati, Ayurvediya Prasuthi tantra evum Stree roga, Part- 2, Choukambha orientalia, Varanasi, Edition- 2 ${ }^{\text {nd }}$, Reprint- 2009, Chapter-4, Yonisrava, page no- 266

8. Dutta D.C, Textbook of Gynaecology, Calcutta, New Central Book Agency(p) Ltd, West Bengal, edition$5^{\text {th }}, 2008$, revised reprint, page no- 153

9. Dr Reddy K Rama Chandra, Bhaisjya Kalpana Vijynanam, second edition- 2011, Chaukhambha Sanskrit bhavan, Varanasi, page- 189-190

10. Tivari Premvati, Ayurvediya Prasuthi tantra evum stree roga, Part- 2, Choukambha orientalia, Varanasi, Edition- $2^{\text {nd }}$, Reprint- 2011, Stree Sharrera Rachana Chapter-1, page no- 6

\section{Source of Support: Nil Conflict of Interest: None Declared}

How to cite this URL: Krishnapriya N \& Kavitha B K: Ayurvedic Concept Of Leucorrhoea: Sweta Pradara. International Ayurvedic Medical Journal \{online\} 2021 \{cited September 2021\} Available from: http://www.iamj.in/posts/images/upload/2196_2200.pdf 